\title{
Development and validation of UPLC method for simultaneous estimation of Efavirenz and Lamivudine in pharmaceutical formulations
}

\author{
Madhusudhanareddy Induri ${ }^{1 *}$, Bhagavan Raju Mantripragada ${ }^{2}$, Rajendra Prasad Yejella ${ }^{3}$ \\ ${ }^{1}$ JNTU Kakinada, Kakinada-533 003, Andhra Pradesh, India. ${ }^{2}$ Department of Pharmaceutical Chemistry, Sri Venkateshwara College of Pharmacy, \# 86, \\ Hitech City Road, Madhapur-500 081, Hyderabad, Telangana, India. ${ }^{3}$ Department of Pharmaceutical Chemistry, College of Pharmaceutical Sciences, \\ Andhra University, Visakhapatnam-530 003, Andhra Pradesh, India.
}

\begin{tabular}{l} 
ARTICLE INFO \\
\hline Article history: \\
Received on: $11 / 01 / 2016$ \\
Revised on: 09/02/2016 \\
Accepted on: 04/03/2016 \\
Available online: $30 / 03 / 2016$ \\
\hline Key words: \\
Efavirenz, Lamivudine, \\
UPLC, Method \\
Development.
\end{tabular}

\section{INTRODUCTION}

Nucleoside reverse transcriptase inhibitors (NRTIs) were the first class of drugs that were introduced as antiretroviral agents for the treatment of infection with human immune deficiency virus (HIV). Additional drug classes were developed. They are protease inhibitors (PIs), non-nucleoside reverse transcriptase inhibitors (NNRTIs), fusion inhibitors (Farmer et al., 2001). Efavirenz, chemically (4S)-6-chloro-4-(2cyclopropylethynyl)-4-(trifluoromethyl)-2, 4-dihydro-1H-3, 1benzoxazin-2-one, is a non-nucleoside reverse transcriptase inhibitor. It is used in the treatment of HIV infection (Figure 1). It binds directly and reversibly to the catalytic site of the reverse transcriptase enzyme and therefore, interferes with viral RNA to DNA directed polymerase activities (Adkins and Noble 1998). Lamivudine, chemically 4-amino-1-\{(2R, 5S)-2-(hydroxyl methyl)-1, 3-oxathiolan-5-yl -1, 2-dihydropyrimidin-2-one, is a nucleoside reverse transcriptase inhibitors with activity against

\footnotetext{
* Corresponding Author

Madhusudhanareddy Induri, Research Scholar, JNTU Kakinada,

Kakinada, Andhra Pradesh, India. Email: msreddyinduria[at]yahoo.com
}

human immune deficiency virus (HIV) and hepatitis B virus (Figure 2) (Zhou et al., 2006; Van et al., 2000).

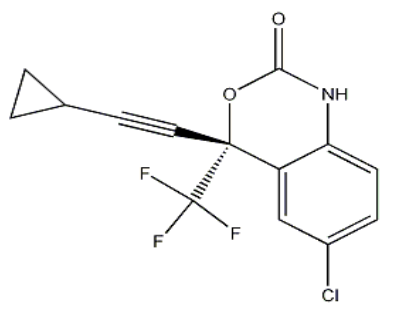

Fig1: Chemical Structure of Efavirenz.

The literature survey reveals that several analytical methods have been reported for the quantification of these drugs individually or in combination with other drugs in pharmaceutical dosage forms or in human plasma by high performance liquid chromatography (Manikanta et al., 2012; Anandakumar et al., 2013; Akula et al., 2014; Naga Sandhya et al., 2013), Liquid chromatography/tandem mass spectrometry (Manish et al., 2012; Rower et al., 2012; Li et al., 2010; Kumar et al., 2013), UPLC (Madeesh et al., 2012; Marina et al., 2011) and high performance thin layer chromatography (Hamrapurkar et al., 2009). 
Present study involves development and validation of UPLC method for the simultaneous estimation of efavirenz and lamivudine in combined tablet dosage form, which is fast, sensitive with better resolution and peak symmetry. Finally, the developed method was validated to assess the validity of research data means determining whether the method used during the study can be trusted to provide a genuine, account of the intervention being evaluated.

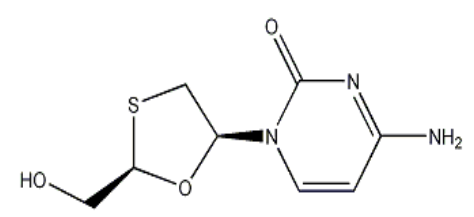

Fig. 2: Chemical Structure of Lamivudine.

\section{MATERIALS AND METHODS}

\section{Materials}

Pure efavirenz (EFV) and lamivudine (3TC) used as working standards, were gifts from Hetero Drugs Pvt. Ltd., Hyderabad, India. Methanol, acetonitrile and water (HPLC-grade) were purchased from Rankem, India. All other chemicals and reagents employed were of analytical grade, and purchased from Rankem, India. A commercial odivir tablets containing $300 \mathrm{mg}$ of lamivudine and $600 \mathrm{mg}$ of efavirenz were obtained from local pharmacies and used within their shelf life period.

\section{Instrumentation and chromatographic conditions}

The Waters Acquity ${ }^{\mathrm{TM}}$ UPLC M-class system consisting of a H05UPB062M binary gradient pump, an inbuilt auto sampler, Water 2996 PDA detector and column oven connected to a multi instrument data acquisition and processing system with Empower 2.1 version. The column used for chromatographic separations was Acquity UPLC BEH Shield RP18 $(50 \times 3$ mm, $1.7 \mu \mathrm{m})$.

Table 1: Optimized Chromatographic Conditions.

\begin{tabular}{ll}
\hline Parameters & Conditions \\
\hline Column & Acquity UPLC BEH Shield RP18 $(50 \times 3 \mathrm{~mm}, 1.7 \mu \mathrm{m})$ \\
Mobile Phase A & $10 \mathrm{mM}$ Phosphate buffer $(\mathrm{pH}=4.0)$ \\
Mobile Phase B & $10 \%$ Acetonitrile in Methanol \\
Gradient Elution & As per Table 2 \\
Flow Rate & $0.4 \mathrm{~mL} / \mathrm{min}$ \\
Wavelength & $254 \mathrm{~nm}$ \\
Injection Volume & $10 \mu \mathrm{L}$ \\
Column Oven Temp. & $35^{\circ} \mathrm{C}$ \\
Run Time & $3.0 \mathrm{Min}$ \\
\hline
\end{tabular}

Table 2: Gradient Programming of proposed method.

\begin{tabular}{cccc}
\hline Time (min) & $\begin{array}{c}\text { Flow Rate } \\
(\mathbf{m L / m i n})\end{array}$ & $\begin{array}{c}\text { \% Mobile } \\
\text { Phase A }\end{array}$ & $\begin{array}{c}\text { \% Mobile } \\
\text { Phase B }\end{array}$ \\
\hline Initial & 0.4 & 82 & 18 \\
1.0 & 0.4 & 65 & 35 \\
1.8 & 0.4 & 50 & 50 \\
2.5 & 0.4 & 82 & 18 \\
\hline
\end{tabular}

The UPLC system was operated gradient mode with mobile phase consisting of $10 \%$ acetonitrile in methanol and 10 $\mathrm{mM}$ phosphate buffer ( $\mathrm{pH}$ adjusted to 4.0) at a flow rate of 0.4 $\mathrm{mL} / \mathrm{min}$ within a run time at $3 \mathrm{~min}$ (Table 1-2). Prior to use, the mobile phase was degassed by an ultrasonic bath and filtered by a millipore vacuum filter system equipped with a $0.2 \mu \mathrm{m}$ high vacuum filter. Both drugs were detected and quantified at $254 \mathrm{~nm}$.

\section{Preparation of standard solutions}

A mixed standard stock solution of EFV $(1000 \mu \mathrm{g} / \mathrm{mL})$ and 3TC $(1000 \mu \mathrm{g} / \mathrm{mL})$ was prepared by accurately weighing 100 $\mathrm{mg}$ of each EFV and 3TC, and dissolved in $100 \mathrm{~mL}$ volumetric flask containing $30 \mathrm{~mL}$ methanol and the flask was sonicated to dissolve the contents and made up to the mark with methanol. Aliquots of these solution was transferred into $100 \mathrm{~mL}$ volumetric flask containing $30 \mathrm{~mL}$ methanol, sonicated for $2 \mathrm{~min}$ and the remaining volume was made up to mark with methanol to get final concentration of $100 \mu \mathrm{g} / \mathrm{mL}$ of each analyte.

\section{Method Validation}

The method was validated in accordance with ICH guidelines (ICH - Q2 (R1)).

\section{System Suitability}

To ensure the validity of the analytical procedure, a system suitability test was established. The following parameters like asymmetry factor, theoretical plate number $(\mathrm{N})$, resolution (Rs) and retention time $\left(t_{R}\right)$ were analyzed by using $10 \mu \mathrm{L}$ of the working standard solution containing EFV $(40 \mu \mathrm{g} / \mathrm{mL})$ and 3TC $(20 \mu \mathrm{g} / \mathrm{mL})$ injecting six times into UPLC system.

\section{Linearity}

Calibration curves were constructed by plotting peak areas versus concentrations of EFV and 3TC, and the regression equations were calculated. The calibration curves were plotted over the concentration range $10-60 \mu \mathrm{g} / \mathrm{mL}$ for EFV and $5.0-30$ $\mu \mathrm{g} / \mathrm{mL}$ for $3 \mathrm{TC}$. Aliquots $(10 \mu \mathrm{l})$ of every solution were injected and analysed under the operating chromatographic conditions described as above.

\section{Detection limit and quantitation limit}

Limit of detection (LOD) and Limit of quantification (LOQ) were calculated based on the ICH guidelines.

\section{Accuracy}

The accuracy was carried out by adding known amounts of each standard drug corresponding to three concentration levels 50,100 and $150 \%$ - of the labeled claim to the analytes. At each level, three determinations were performed and the results were recorded. The accuracy was expressed as percent analyte recovered by the proposed method.

\section{Precision}

The precision of the method was checked by repeatability of injection, repeatability (intra-assay), intermediate precision (inter-assay) and reproducibility. Injection repeatability was studied by calculating the percentage relative standard deviation (\% RSD) for ten determinations of peak areas of EFV $(30 \mu \mathrm{g} / \mathrm{mL})$ 
and 3TC $(15 \mu \mathrm{g} / \mathrm{mL})$, performed on the same day. For both intraand inter-assay variation, sample solutions of EFV (20, 30 and 40 $\mu \mathrm{g} / \mathrm{mL})$ and $3 \mathrm{TC}(10,15$ and $20 \mu \mathrm{g} / \mathrm{mL})$ were injected in triplicate.

\section{Robustness}

The robustness of the proposed method was determined by carrying out the analysis, during which flow rate (varied by \pm $0.02 \%$ ), and buffer $\mathrm{pH}$ (varied by \pm 0.1 ) were altered, and the peak areas, retention times and no. of theoretical plates were noted.

\section{RESULTS AND DISCUSSIONS}

The UPLC method, as described, was validated and successfully employed for the simultaneous quantification of EFV and 3TC in tablets. There is need to consider the successive steps for the development of UPLC method. In particular, the problems relating to the standardization of sample preparations and selection of mobile phase needs to be emphasized. The optimized chromatographic conditions were selected based on sensitivity, retention time, peak shape and baseline drifts. The method was selective for the determination of EFV and 3TC since no interfering peaks appeared near the retention time of the compound of interest. A typical chromatogram recorded at $254 \mathrm{~nm}$ is shown in Figure 3. The retention times of EFV and 3TC at a flow rate of $0.4 \mathrm{~mL} / \mathrm{min}$ were 0.921 and $1.981 \mathrm{~min}$, respectively. The analyte peaks were well resolved and were free from tailing (< 2 for both the analytes). To ensure the validity of a system and analytical method, system suitability test was performed. The percent relative standard deviation (\%RSD) of the retention times (RT) and peak areas of EFV and 3TC from the six consecutive injections of the standard solutions were 0.852 and 0.624 , and
1.215 and 1.725 , respectively. The tailing factor for EFV and 3TC peaks were 1.32 and 1.47 , respectively, thus reflecting good peak symmetry. The resolution (Rs) between two analytes was 3.35, indicating good separation of both analytes from each other. The theoretical plate no. for EFV and 3TC were 12448 and 10275, respectively, thus indicating good column efficiency. The calibration curve obtained by plotting peak area against concentration showed linearity in the concentration range of 10-60 $\mu \mathrm{g} / \mathrm{mL}$ for $\mathrm{EFV}$ and $5-30 \mu \mathrm{g} / \mathrm{mL}$ for 3TC. The regression coefficients of EFV $\left(r^{2}=0.9991\right)$ and 3TC $\left(r^{2}=0.9992\right)$ indicate a good linear relationship between peak area versus concentration over a wide range. LOD for EFV and 3TC was 0.12 and 0.04 $\mu \mathrm{g} / \mathrm{mL}$, respectively, while LOQ was $0.37 \mu \mathrm{g} / \mathrm{mL}$ and $0.13 \mu \mathrm{g} / \mathrm{mL}$, respectively. The mean recoveries obtained for EFV and 3TC were $99.92-100.52 \%$ and $99.48-100.66 \%$, respectively, indicating that the developed method was accurate (Table 3).

Injection repeatability values (\%RSD) of EFV and 3TC were found to be 0.813 and 1.266 , respectively. Results for intra and inter-assay precision, expressed as \% RSD, results were given in Table 4. The low values of \%RSD indicate that the method is precise. Reproducibility was checked by analyzing the samples by another analyst using same instrument and same laboratory. There was no significant difference between \%RSD values, which indicates that the proposed method was reproducible. There was no significant change in the peak areas, retention times and no. of theoretical plates of EFV and 3TC when the flow rate and $\mathrm{pH}$ of buffer were changed, indicate that the method was robust (Table 5). The results of the assay yielded $100.79 \%$ for EFV and 100.33 $\%$ for 3TC, of label claim of the tablets. The assay results show that the method was selective for the simultaneous determination of EFV and 3TC without interference from the excipients used in the tablet dosage form and the results were shown in the Table 6.

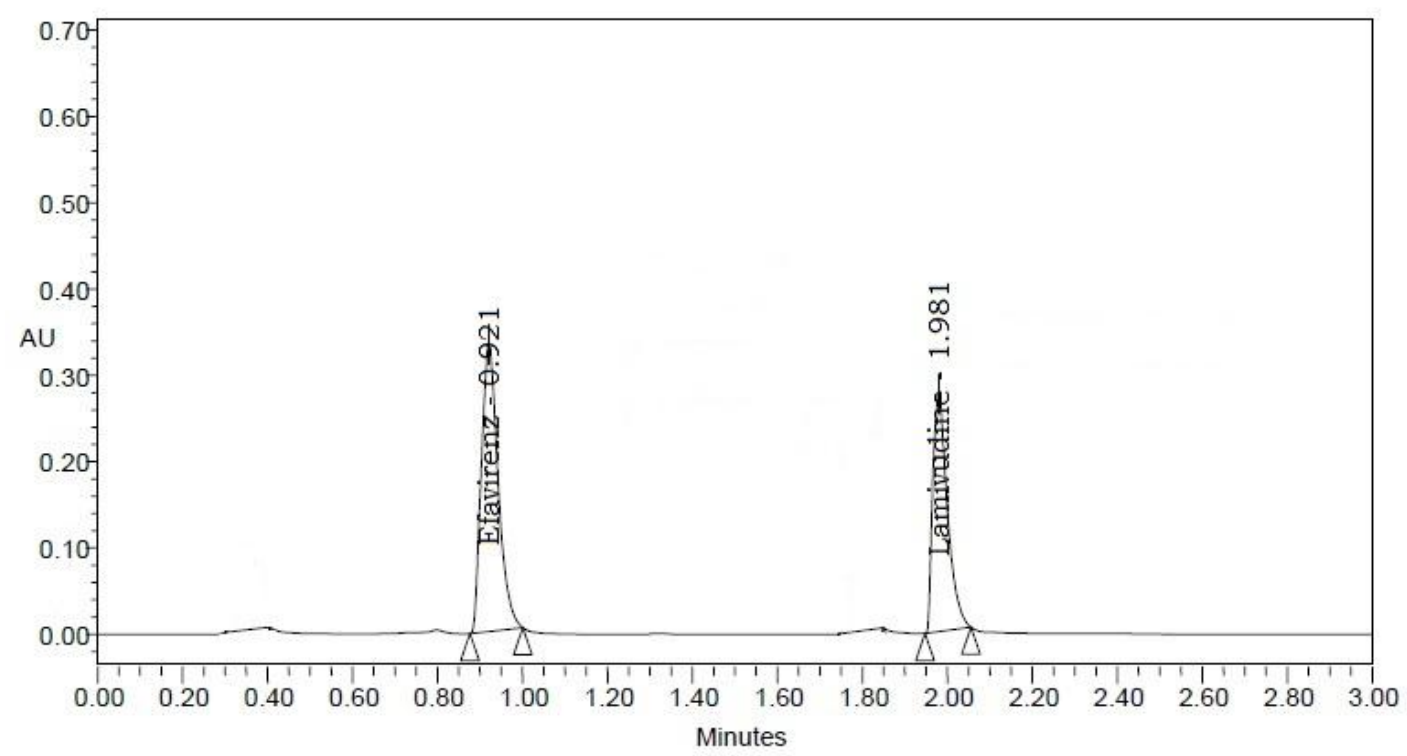

Fig. 3: A typical chromatogram of standard efavirenz $\left(t_{R}: 0.921\right)$ and lamivudine $\left(t_{R}: 1.981\right)$. 
Table 3: Results of recovery studies by standard addition method.

\begin{tabular}{|c|c|c|c|c|c|c|}
\hline \multirow{2}{*}{ Analyte } & \multicolumn{2}{|c|}{ Amount of standard drug spiked } & \multirow{2}{*}{$\begin{array}{c}\text { Amount of sample taken } \\
(\mathrm{mg})\end{array}$} & \multirow{2}{*}{$\begin{array}{c}\% \text { Recovery }(\text { Mean } \pm \text { SD }) \\
\{\text { three replicates }\}\end{array}$} & \multirow[b]{2}{*}{ RSD $(\%)$} & \multirow{2}{*}{$\begin{array}{c}\text { Standard error of } \\
\text { mean }\end{array}$} \\
\hline & \% Spiked & Quantity (mg) & & & & \\
\hline \multirow{3}{*}{ EFV } & 50 & 300 & 600 & $99.92 \pm 0.697$ & 0.697 & 0.4023 \\
\hline & 100 & 600 & 600 & $100.44 \pm 0.815$ & 0.812 & 0.4707 \\
\hline & 150 & 900 & 600 & $100.52 \pm 1.405$ & 1.398 & 0.8111 \\
\hline \multirow[t]{3}{*}{ 3TC } & 50 & 150 & 300 & $99.48 \pm 1.360$ & 1.367 & 0.7850 \\
\hline & 100 & 300 & 300 & $100.66 \pm 1.665$ & 1.654 & 0.9615 \\
\hline & 150 & 450 & 300 & $99.84 \pm 1.101$ & 1.103 & 0.6359 \\
\hline
\end{tabular}

Table 4: Precision data of the proposed method.

\begin{tabular}{|c|c|c|c|c|c|}
\hline \multirow{2}{*}{ Analyte } & \multirow{2}{*}{$\begin{array}{l}\text { Analyte Conc. } \\
(\mu \mathrm{g} / \mathrm{mL})\end{array}$} & \multirow{2}{*}{ Intra-assay precision* } & \multirow{2}{*}{ Inter-assay precision* } & \multicolumn{2}{|c|}{ Reproducibility* } \\
\hline & & & & Analyst one & Analyst two \\
\hline \multirow[t]{3}{*}{ EFV } & 20 & 0.867 & 0.799 & 1.018 & 1.004 \\
\hline & 30 & 1.302 & 1.243 & 0.985 & 1.438 \\
\hline & 40 & 1.368 & 1.595 & 0.799 & 1.037 \\
\hline \multirow[t]{3}{*}{ 3TC } & 10 & 0.769 & 0.812 & 1.328 & 1.095 \\
\hline & 15 & 1.024 & 1.215 & 0.611 & 0.478 \\
\hline & 20 & 0.214 & 1.341 & 1.001 & 0.179 \\
\hline
\end{tabular}

*\% RSD Values.

Table 5: Results for robustness of the proposed method.

\begin{tabular}{|c|c|c|c|c|c|}
\hline \multirow{2}{*}{ Parameter } & \multirow{2}{*}{ Used } & \multirow{2}{*}{ Analyte } & Retention time & Tailing Factor & No. of Theoretical Plates \\
\hline & & & Mean \pm SD* & Mean \pm SD* & Mean \pm SD* \\
\hline \multirow{6}{*}{$\begin{array}{l}\text { Flow rate } \\
(\mathrm{mL} / \mathrm{min})\end{array}$} & 0.38 & \multirow{3}{*}{ EFV } & $1.008 \pm 0.003$ & $1.23 \pm 0.020$ & $11230 \pm 178$ \\
\hline & 0.4 & & $0.924 \pm 0.004$ & $1.33 \pm 0.015$ & $12515 \pm 205$ \\
\hline & 0.42 & & $0.911 \pm 0.006$ & $1.45 \pm 0.021$ & $10580 \pm 148$ \\
\hline & 0.38 & \multirow{3}{*}{$3 \mathrm{TC}$} & $1.856 \pm 0.009$ & $1.34 \pm 0.021$ & $9763 \pm 103$ \\
\hline & 0.4 & & $1.783 \pm 0.005$ & $1.46 \pm 0.006$ & $10296 \pm 47$ \\
\hline & 0.42 & & $1.762 \pm 0.006$ & $1.39 \pm 0.015$ & $9792 \pm 61$ \\
\hline \multirow{6}{*}{$\mathrm{pH}$ (Buffer) } & 3.9 & \multirow{3}{*}{ EFV } & $0.931 \pm 0.014$ & $1.21 \pm 0.015$ & $10351 \pm 104$ \\
\hline & 4.0 & & $0.921 \pm 0.008$ & $1.34 \pm 0.010$ & $12625 \pm 156$ \\
\hline & 4.1 & & $0.915 \pm 0.007$ & $1.41 \pm 0.023$ & $10507 \pm 138$ \\
\hline & 3.9 & \multirow{3}{*}{$3 \mathrm{TC}$} & $1.826 \pm 0.022$ & $1.31 \pm 0.015$ & $9768 \pm 86$ \\
\hline & 4.0 & & $1.775 \pm 0.009$ & $1.45 \pm 0.015$ & $10436 \pm 156$ \\
\hline & 4.1 & & $1.756 \pm 0.015$ & $1.39 \pm 0.015$ & $9754 \pm 89$ \\
\hline
\end{tabular}

*Replicates of three injections.

Table 6: Assay results for efavirenz and lamivudine in tablets.

\begin{tabular}{cccccc}
\hline Product & Analyte & Label claim per tablet $(\mathbf{m g})$ & \% analyte estimated (Mean \pm SD)* & RSD (\%) & SEM \\
\hline \multirow{2}{*}{ Odivir } & EFV & 600 & $100.79 \pm 0.513$ & 0.509 & 0.296 \\
& 3TC & 300 & $100.33 \pm 1.193$ & 1.189 & 0.689 \\
\hline
\end{tabular}

$* n=3 ;$ SEM $=$ standard error of mean.

\section{CONCLUSION}

A convenient, rapid, accurate and precise UPLC method was developed for the simultaneous determination of efavirenz and lamivudine in pharmaceutical formulations. The assay provides a linear response across a wide range of concentrations. This method can be said to be more economical as compared to other methods reported in literature. The method suitable for the determination of these drugs in tablets, and hence can be used for routine quality control of efavirenz and lamivudine in this dosage form.

\section{REFERENCES}

Adkins J.C., Noble S. Efavirenz. Drugs 1998, 56 (6), 1055.

Akula Srinath, B. Sneha, Akhila Alladi, Rayees Ahmed, R.G. Kulkarni. Method development and validation for simultaneous estimation of lamivudine, tenofovir and efavirenz in combined tablet dosage form by RP-HPLC and UV-spectroscopic method. Int J Pharm Sci Res, 2014; 5(12): 5491-7.

B. Naga Sandhya, A. Manikanta Kumar, Mahesh K Nasare, P. Vijay Kumar, Jetta Satish, Prakash. V. Diwan. RP-HPLC method for simultaneous estimation of lamivudine, didanosine and efavirenz in pharmaceutical dosage forms. Der Pharmacia Lettre, 2013; 5(3): 148-55.

Farmer Paul, Léandre Fernet, Mukherjee Joia, Gupta Rajesh, Tarter Laura, Kim Jim Yong. Community-based treatment of advanced HIV disease: introducing DOT-HAART (directly observed therapy with highly active antiretroviral therapy). Bull World Health Organ, 2001; 79(12): 1145-51.

Hamrapurkar P., Phale M., Shah N. Quantitative Estimation of Efavirenz by High Performance Thin Layer Chromatography. J Young Pharm, 2009; 1(4): 359-63.

International Conference on Harmonization (ICH) of Technical Requirements for the Registration of Pharmaceuticals for Human Use, Validation of Analytical Procedure: Text and Methodology $\{\mathrm{ICH}-$ Q2(R1)\} November 2005: 1-13.

K. Anandakumar, G. Abirami, S. Murugan, B. Ashok. RPHPLC method for simultaneous estimation of lamivudine, tenofovir disoproxil fumarate and efavirenz in tablet formulation. J Anal Chem, 2013; 68(9): 815-21.

Kumar V.R., Reddy B.P., Kumar B.R., Sreekanth K., Babu K.N. High throughput LC-MS/MS method for simultaneous determination of zidovudine, lamivudine and nevirapine in human plasma. J Chromatogr B Analyt Technol Biomed Life Sci, 2013; 15(921-922): 9-14.

Li Z., Ding C., Ge Q., Zhou Z., Zhi X., Liu X. Simultaneous determination of lamivudine, stavudine and nevirapine in human plasma 
by LC-MS/MS and its application to pharmacokinetic study in clinic. Biomed Chromatogr, 2010; 24(9): 926-34.

Manikanta Kumar A, B. Naga Sandhya, Mahesh Nasare, V. V. L. N Prasad, Prakash V. Diwan. Development and Validation of RP-HPLC method for simultaneous estimation of Lamivudine and Efavirenz in the Pharmaceutical Dosage Form. J Adv Pharm Edu Res, 2012; 2(4): 232-8.

Manish Yadav, Puran Singhal, Sailendra Goswami, Umesh C. Pande, Mallika Sanyal, Pranav S. Shrivastav. Selective Determination of Antiretroviral Agents Tenofovir, Emtricitabine, and Lamivudine in Human Plasma by a LC-MS-MS Method for a Bioequivalence Study in Healthy Indian Subjects. J Chromatogr Sci, 2010; 48: 704-13.

Marina V. Antunes, Julia Poeta, Jorge P. Ribeiro, Eduardo Sprinz, Rafael Linden. Ultra-performance liquid chromatographic method for simultaneous quantification of HIV non-nucleoside reverse transcriptase inhibitors and protease inhibitors in human plasma. J Braz Chem Soc, 2011; 22(1): 134-41.

Rower J.E., Klein B., Bushman L.R., Anderson P.L. Validation of a sensitive LC/MS/MS method for the determination of zidovudine and lamivudine in human plasma. Biomed Chromatogr, 2012; 26(1): $12-20$
Sk. Madeesh, Y. Ismail and V. Gunasekaran. Development and validation for simultaneous estimation of lamivudine, tenofovir and efavirenz by UPLC. Int J Pharm, 2012; 2(3): 656-60.

Van Rompay A.R., Johansson M., Karlsson A. Phosphorylation of nucleosides and nucleoside analogs by mammalian nucleoside monophosphate kinases. Pharmacol Ther, 2000; 87(2-3): 189-98.

Zhou Z, Rodman J.H., Flynn P.M., Robbins B.L., Wilcox C.K., D'Argenio D.Z. Model for intracellular Lamivudine metabolism in

\section{How to cite this article:}

Induri M., Mantripragada BR, Yejella RP. Development and Validation of A UPLC Method for Simultaneous Estimation of Efavirenz and Lamivudine in Pharmaceutical Formulations. J App Pharm Sci, 2016; 6 (03): 029-033. 